\title{
Kortárs dán építészet- ember központúság és racionalitás
}

\section{Conemporary Danish architecture- humanity and rationality}

\section{T. CSÉPKE ${ }^{1}$ T.SZENTIRMAI ${ }^{2}$}

\author{
1Debreceni Egyetem Műszaki Kar, csepke.tamas@gmail.com \\ 2 Debreceni Egyetem Műszaki Kar, szentirmai.tamas@gmail.com
}

\begin{abstract}
Absztrakt. A TDK dolgozatom témájában a kortárs dán építészet stílusjegyeit és azok kialakulását kutattam. Dániában mély társadalmi beágyazódás alakult ki. Az építészeti törekvések erốteljesen reflektálnak az adott kor szociális problémáira, figyelembe véve a környezeti aspektusokat. Az ország építészetére jellemző a regionalista felfogás, emiatt a stílusirányzatok sajátos formában jelennek meg az építészetben. Ön reflexív és elemző hozzáállással a dán építészek napjainkban is válaszokat próbálnak megfogalmazni a kor kérdéseire, még inkább hangsúlyozva az emberi tényezô lényegét.
\end{abstract}

Abstract. In my study I have examined the characteristics of contemporary Danish architecture and the way how they formed. In Denmark, there is strongly rooted social atmosphere. The architectural efforts strongly reflects the social problems every time, considering the environmental aspects. The regionalist methods appear in the architecture, because of this the different architectural styles appear specific way. Self-reflective and analytical way the Danish architects try to answer the contemporary issues, even more emphasize the human factor.

\section{Bevezetés}

$\mathrm{Az}$ élhető élettér megteremtése megkerülhetetlen szempont ma már az építészetben. Az épület nemcsak önálló tárgy a térben, hanem szerves elegyet alkot a befogadó környezettel, ezáltal összefüggő szövetként biztosít hátteret a mindennapoknak. A társadalmi kontextus szerepe a téma boncolgatása során elengedhetetlen. Az inspiratív környezet megteremtése az, ami ma a dán építészek szeme előtt lebeg.

A nagyon erős társadalmi beágyazottság, ami kialakult a történelem folyamán, meghatározó tényezőjévé vált a környezet alakításának. Az építészet koherenciaként működik az ország életében, gyorsan reagálva a társadalmi változásokra. Az évek alatt számos tényező részévé vált a tervezési szempontoknak, mindig az adott kor igényeit figyelembe véve. Mára, a fenntarthatóság és 
környezettudatosság legalább olyan fontos és szerves részévé vált a dán építészetnek, mint az említett emberközpontúság, kiteljesítve azt.

A dolgozat témájában a dán építészetet, a kialakult gondolkodásmódot és az új generáció munkásságának inspiráló okait szeretném feltárni, a tényezőket melyek alátámasztják a nyitó gondolatot. A XX. század építész generációja alapjaiban határozza meg azt a szellemi alapot, amiből az utódok meríthettek, ötvözve a klasszikus stílusjegyeket a globalizált hatásokat.

\section{A társadalom és tradíciók szerepe a dán építészetben}

A dán építészet elemzése során megfigyelhető, hogy társadalom hangsúlyozása nemzeti identitásként jelenik meg. A külső hatások adaptálása, mindig reflektál a hagyományok felé és sajátos dán formában valósulnak meg. Az építészet a használhatóságra, a helyi építőanyagok alkalmazására, racionális szerkesztésmódra törekedett. Dán jellemző a közösség és környezet kapcsolata, illetve a retrospektív, elemző szemléletmód.

Fontos megjegyezni, hogy idegen nép nem özönlötte el az országot, így a régi kultúra sokáig fennmaradt és a népességnek volt ideje a külső hatások feldolgozására. Az ország sajátossága, hogy kicsinysége és intenzív betelepülése miatt a táj és építészet minden esetben kiegyensúlyozott harmonikus kapcsolatban van egymással. Lankás tájakon a dombok lejtőin védett helyek találhatók a települések, de a tengerpartok mentén az öblöket szegélyező városok is hasonló kialakítást sugároznak. A történelem folyamán társadalom centrikusság problémamegoldó eszközzé formálódott, ami már a viking korabeli település szerkezetben is megmutatkozott. Ebben az időben a kiscsoportos településforma terjedt el a szárazföldön belül és a tengerek, fjordok közelében is, jellemzően szorosan egymás közelébe épített házakkal.

A jóléti társadalom megalkotása a világháborúk közti években megreformálta az ország szociális felépítését és a mai napig mélyen befolyásolja azt. A különböző szektorok fejlesztése: oktatás, szociális ellátás, egészségügy és egyéb infrastruktúrák kiegyensúlyozott rendszerben szoros kapcsolatban állnak egymással, amiben az egyik szektor determinálja a másikat. A társadalom felépítésre jellemző, hogy a közös jólét és egyenlő esélyek megteremtése nemzeti karakterként van jelen.

Az építészetre jellemző a regionalista felfogás, ami az éghajlati, táji adottságok, anyagkínálat által befolyásolta a nemzetközi impulzusokat. Ez a felfogás általában a skandináv országokra jellemző. Szerényebb, természetesebb, majdnem eszköztelen, enyhén hagyományos forma alakult ki, ami mégis átveszi a modern szellemiséget, de annak formai túlzásait kevésbé örökíti át. A modern civilizációba való részvételhez szükség van a tudományos, technikai, a politikai racionalitás átvételére, ami a kulturális múlt újra értelmezését igényli, de tény hogy nem minden társadalom képes feldolgozni a modern civilizáció keltette megrázkódtatásokat.

Hogyan lehet korszerűvé válni, de ugyanakkor visszatérni az eredetihez is, hogyan lehet feltámasztani a múlt szunnyadását, civilizációját és részévé válni az egyetemes civilizációnak: ezen ellentmondás körül egyensúlyoz a dán építészet történelem folyamán. ${ }^{1}$ 


\section{XIX. századig végbemenő változások}

Az ország építészetének kialakulása mély társadalmi és kulturális beágyazottságon alapul. A sokszínű alkotói hozzá állás és az ország szellemi hagyatéka közös alapot biztosít az építészek számára. A hagyományok mellett megfigyelhető, egyfajta nagyon tudatos magatartás és szándék, az alakításban és a környezettel való interakció során, valamint a problémák feltárása és megoldása irányába. Az építészeti gondolatok szorosan kapcsolatban vannak az ország történetével, de nem hatalmi célokat szolgálnak, sokkal inkább a társadalmi szükségletekre reagálnak.

A településképben az 1700-as évek folyamán kardinális változás következett be. A Rousseau-i gondolatok - „vissza a természetbe” - hatása volt ez a felvilágosodáson keresztül, amik kielégítették az urbánus felső társadalmi osztály igényét azáltal, hogy természetközelibb helyzetbe kerültek. Az 1850es években következett egy újabb változás, amikor a liberális eszmék hatására az addigi monarchikus államforma megváltozott. Ebben az időszakban a nagyvárosok még a klasszikus formákat követték, erődrendszerü, körkörös kialakítás volt jellemző. A népességük igen magas volt, és nagyon sűrű városszövet alakult ki.

Az iparosodás folyamata az 1900-as évek elején nagy hatást gyakorolt az országra. Új anyagok megjelenése, mint a beton, változtatott az épületek kivitelezésében és új típusok is megjelentek. Ezzel párhuzamosan az elővárosi területeken a zöld övezetbe helyezett épületek, ideális keretet adtak a családi életnek és a hagyományos vidéki ház kultúráját idézték. Nagyon széles spektrum bontakozott ki az építészet palettáján.

Elmondható, hogy a kezdeti településformák, amik szoros kapcsolatban álltak a tájjal, meghatározó tényezővé váltak a későbbi évszázadokban is. A kis közösségek védelmező szerepe tiszta egyszerű kapcsolatot létesített a tájjal, ami alapjaiban határozza meg az tömegszervezést és építészeti formálást.

\section{A XX. század dán építészete}

A XX. század folyamán a világháborúk meghatározó szerepet töltöttek be a kontinens életében, amik új problémák elé állították az építészeket. Az első világháború kaotikus szociális állapotokat hagyott maga után, így lakhatás központi problémává vált a század elején.

A legszembetűnőbb fejlesztések a szociális lakásprogramok voltak, hangsúlyozva a társadalom gondoskodó hatását. Az évek alatt tárgyilagos építészet alakult ki, nagyon gyakorlatias egyszerű szemléletmód, amely mélyen beágyazódott, ez befolyásolta a nemzetközi modernizmus terjedését, így az másképp jelent meg az országban és nem volt eluralkodó, inkább integrálódott. A város, mint befogadó közeg is egyre inkább a figyelem központjába került és szem előtt van a mai napig. Az európai építészeket is foglalkoztatta a kérdéskör. 1923-ban Le Corbusier Az új építészet felé - című művében modern élet szükségleteiről ír, valamint új tervezési szemlélet kialakulásáról a város és lakhatás szintjén is. Az új gondolatok által megkísérelték megújítani az épített környezetet, javítani az életkörülményeket. Emberi környezetet teremteni a káosszal egy időben, amikor az iparosítás 
destruktív hatásai megmutatkoztak a sűrűn lakott városok és szociális problémák formájában.1 Ezek a kihívások hosszan kísérték a dán építészetet a XX. század folyamán.A kulturális modernizmus egyre elfogadottabbá vált és célja volt, hogy támogassa, segítse a demokratikus osztály nélküli szociális rendszert, amely mentes minden anakronisztikus örökségtől. A racionális várostervezés és a lakozás újra aktív kapcsolatban a környezettel mind fontos tételekké váltak.

A különböző stílusok, mindig megérintették az ország építészetét, de sose jelentek meg egyeduralkodó formában. A dán építészet a regionalista felfogását megtartva tudta adaptálni a modern hatásokat és hozott létre sajátos arculatot, úgy hogy a társadalmi igényeket szem előtt tartva fejeződik ki ritmusban, fényben és szerkezetben.

\section{Kortárs dán építészet}

Az ezredforduló környékén nagyon lendületes új energiával teli generáció jelent meg az ország építészetében. A hatás annyira erőteljes volt, hogy sokan az új hullám jelzőt használják a definiálásukra. A kritikusok szerint a generáció képes adoptálni magát a kor kihívásaihoz és az építészetet olyan formába önteni, ami adekvát választ ad XIX. századi kihívásokra, mindehhez felhasználva a kor adta lehetőségek teljes tárházát. A külső hatások korunkban is megérintették az ország építészeit. Sok fiatal építész a holland hatásokra hivatkozik. Ezt kritikus hangok illetik amiatt, hogy túl nagy befolyást enged a globalizációnak és elveszti az örökségét. A megújult formálás és megoldások mellett elmondható, hogy a dán építészet ma is pragmatikus, bátran használja az anyag és forma kombinációját. A funkció ma sokkal összetettebb , mint néhány évtizeddel ezelőtt, emiatt meg kell próbálni összekötni azokat. Az építészet úgy viselkedik, mint egy összekötő közeg magába foglalva több különböző elemet, élethelyzeteket és gyakorlatokat.

\section{Összegzés}

A kutatásom során arra jutottam dán építészetben nagyon fontos a társadalmi kapcsolatok szerepe, ami az évek alatt mindig a tervezek figyelmében volt, még ha nem is mindig ugyanolyan mértkében. Ennek a jelenségnek a kezdete már az ország korai történelmében is érezhető. Ennek a jelenségnek a kezdete már az ország korai történelmében is érezhető. A természet közelsége, annak kapcsolata az épületekkel az élhető élettér megteremtéséhez alapvető fontosságú. A társadalom megkerülhetetlen az ország történelmében és az építészek is sokszor kiindulási alapként kezelik a problémák megoldásában. A közösségi helyek megteremtését az összetartozás, kapcsolatteremtés inspirálja. Az emberi lépték és az ember felhasználói szerepköri kiemelt figyelmet kapott az évszázadok alatt és ma is legalább olyan fontos. Következtetésként elmondható, hogy a dán építészet újra értelmezés és a társadalmi helyzetek pontos megfejtése alapján fejlődött, önreflexív módon próbál megoldásokat találni az adott időszak problémájára. Az évszázadok alatt kialakult szociális érzékenység és retrospektív munka eredménye az a gondolkodásmód, ami korunk globalizációs hatásaira válaszreakcióként jelenik meg a dán építészetben.

\footnotetext{
${ }^{1}$ Jørgen Sestoft, Jørgen Hegner Christiansen: Guide to Danish Architecture part 1 Arkitektens Forlag Koppenhága 1991
} 
International Journal of Engineering and Management Sciences (IJEMS) Vol.2. (2017). No. 1

DOI: 10.21791/IJEMS.2017.1.2.

\section{Hivatkozások}

[1] Frampton, K. : A modern építészet kritikai története. Terc Kiadó, Budapest, 2002. 